\title{
AKTIVITAS ANTIOKSIDAN EKSTRAK ETIL ASETAT KECAMBAH KEDELAI HITAM (Glycine soja) YANG DIHIDROLISIS DENGAN ASAM KLORIDA
}

\author{
Nurisyah $^{1 *}$, Alfrida Monica Salasa ${ }^{2}$, Elisabeth Natalia Barung ${ }^{3}$, dan Ratna Sari Dewi ${ }^{4}$ \\ 1,2,4 Jurusan Farmasi Poltekkes Kemenkes Makassar \\ ${ }^{3}$ Jurusan farmasi Poltekkes Kemenkes Manado
}

${ }^{*}$ Koresponden : Nurisyah, E-mail : nurisyah31@gmail.com

DOI: https://doi.org/10.32382/mf.v15i1.797

\begin{abstract}
ABSTRAK
Isoflavon dalam kecambah kedelai hitam (Glycine soja) berada dalam bentuk glikosida. Hidrolisis dengan asam dapat mengubah isoflavon glikosida menjadi isoflavon aglikon dan glukosa. Isoflavon diperoleh melalui ekstraksi dengan pelarut etanol dan campuran etanol dan HCL secara maserasi.. Penelitian bertujuan membandingkan aktivitas antioksidan ekstrak tanpa hidrolisis dan yang dihidrolisis. Penelitian dilakukan dengan mengekstraksi senyawa isoflavon dari ekstrak etanol dengan pelarut etil asetat. Selanjutnya dilakukan pengujian aktivitas antioksidan dengan mengukur jumlah DPPH yang tereduksi dari senyawa antioksidan sampel menggunakan spektrofotometer UVVis pada panjang gelombang $517 \mathrm{~nm}$. Aktivitas antioksidan dihitung sebagai \%pengikatan DPPH oleh sampel, kemudian ditentukan nilai $\mathrm{IC}_{50}$ sampel. Hasil penelitian menunjukkan bahwa nilai $\mathrm{IC}_{50}$ ekstrak etil asetat kecambah kedelai hitam tanpa hidrolisis sebesar 341,88 ppm dan ekstrak terhidrolisis sebesar 179,204 ppm. Hal ini menunjukkan bahwa ekstrak terhidrolisis memiliki aktivitas antioksidan 2 kali lebih kuat dari ekstrak tanpa hidrolisis.
\end{abstract}

Kata kunci : kecambah, kedelai hitam, hidrolisis,, aktivitas antioksidan.

\section{PENDAHULUAN}

Konsep "From Food To Cosmetic" menarik perhatian produsen untuk memproduksi kosmetika yang berbahan dasar bahan alam karena selain dinilai lebih aman, kosmetika yang berbahan dasar dari makanan dan tanaman sudah terbukti mempunyai efektivitas yang baik untuk kesehatan maupun kecantikan. Kosmetika bebahan dasar alam juga dinilai lebih ramah lingkungan (Qiushi C., 2009).

Kecambah atau disebut juga tauge merupakan tunas muda dari biji kacangkacangan yang disemaikan. Berdasarkan kandungan kimia kecambah, maka diyakini bahwa kecambah dapat dikembangkan sebagai bahan aktif pembuatan kosmetika skin whitening dan antioksidan. Pemanfaatan kedelai hitam (Glycine soja) kurang mendapat perhatian dan tidak sepopuler kedelai kuning dikarenakan warnanya yang kurang menarik.

Biji kedelai yang mengandung senyawa isoflavon yang termasuk dalam kelompok flavonoid sebagai penghasil antioksidan alami (Astuti et al. 2009, Zaheer dan Akhtar 2017). Isoflavon merupakan senyawa metabolit sekunder yang dapat mencegah penyakit-penyakit degeneratif seperti penuaan dini, dan osteoporosis, mengurangi risiko penyakit kardiovaskular, serta mengurangi sindrom menopause pada wanita (Wong et al. 2008; Xiao 2008; Zhang et al. 2012).

Dibandingkan dengan kedelai kuning, kedelai hitam memiliki kandungan total polifenol, flavonoid dan antosianin yang lebih tinggi daripada kedelai kuning. Berdasarkan hasil penelitian Yuliana (2003), proses perkecambahan dapat meningkatkan produksi senyawa fenolik, dan meningkatkan aktivitas antioksidannya. Devi et al. (2009) melaporkan kandungan total isoflavon varietas kedelai asal India yang diolah menjadi beberapa produk diantaranya kecambah kedelai memiliki kandungan total isoflavon tertinggi dengan kisaran 602-794 $\mathrm{mg} / \mathrm{kg}$, lebih tinggi dibandingkan biji kedelai $(568-730 \mathrm{mg} / \mathrm{kg})$.

Senyawa isoflavon ini pada umumnya berupa senyawa kompleks atau konjugasi dengan senyawa gula melalui ikatan glukosida. Jenis senyawa isoflavon ini terutama adalah genistin, daidzin, dan 
glisitin. Bentuk senyawa demikian ini mempunyai aktivitas fisiologis kecil. Selama proses pengolahan, baik melalui proses fermentasi maupun proses non-fermentasi, senyawa isoflavon dapat mengalami transformasi, terutama melalui proses hidrolisa sehingga dapat diperoleh senyawa isoflavon bebas yang disebut aglikon yang lebih tinggi aktivitasnya.

Isoflavon dalam kedelai terdapat dalam 4 bentuk, yaitu bentuk malonilglikosida, asetil-glikosida, glikosida, dan aglikon (bebas). Kandungan tertinggi isoflavon dalam kedelai adalah malonil- dan asetilglikosida (Kudou et al., 1991). Di antara keempat bentuk isoflavon, aktivitas antioksidatif tertinggi ditunjukkan oleh isoflavon aglikon, terutama genistein. Isoflavon malonil-glikosida dan asetilglikosida mudah terdeesterifikasi menjadi isoflavon glikosida dengan perlakuan suhu tinggi (di atas $40^{\circ} \mathrm{C}$ ) (Kudou et al, 1991). Hidrolisis dengan asam atau enzim $\beta$ glukosidase dapat mengubah isoflavon glikosida menjadi isoflavon aglikon dan glukosa (Purwoko et al, 2001). Oleh karena itu, tujuan penelitian ini adalah untuk mengetahui aktivitas antioksidan ekstrak etil asetat kecambah kedelai hitam yang dihidrolisis maupun tanpa hidrolisis dengan asam klorida.

\section{METODE PENELITIAN \\ Bahan dan Alat}

Bahan utama yang digunakan pada penelitian ini adalah Kedelai hitam organik yang diperoleh dari produsen di Kota Bogor. Bahan pembantu adalah natrium alginat. Bahan kimia yang dibutuhkan adalah etanol, etil asetat, heksan, $\mathrm{HCl}$, DPPH dan akuades.

Alat yang akan digunakan adalah magnetic stirer hot plate, Mikropipet, Rotavapor vakum, cawan porselen, timbangan analitik, Spektrofotometer UVVIS dan alat-alat gelas untuk analisis.

\section{Pembuatan Kecambah}

Biji kedelai hitam direndam dalam larutan natrium alginat $2 \%$ selama 4 jam, kemudian dikecambahkan selama 64 jam (mengacu pada penelitian Pertiwi, 2013)

\section{Proses Ekstraksi}

\section{Ekstraksi tanpa hidrolisis}

Kecambah segar yang telah dibersihkan dikeringkan di udara terbuka dan terlindung dari sinar matahari. Setelah kering, sampel diserbukkan dengan cara diblender dan diayak dengan ayakan mesh 40. Kemudian sampel uji sebanyak $250 \mathrm{~g}$ dimasukkan ke erlemeyer, ditambahkan dengan pelarut dietil eter sebanyak $400 \mathrm{~mL}$. Dishaker selama 4 jam, disaring. Residu dishaker kembali menggunakan etanol $96 \%$ selama 4 jam, proses ekstraksi dilakukan beberapa kali dengan pelarut yang sama sampai diperoleh ekstrak yang tidak berwarna lagi. Campuran disaring menggunakan kertas saring Whatman nomor 41. Filtrat yang diperoleh dipekatkan menggunakan rotavapor. Setelah itu, dilakukan pemisahan dengan etil asetat menggunakan corong pisah. Fraksi etil asetat yang diperoleh kemudian disaring, dan dipekatkan kembali dengan rotavapor. Ekstrak etil asetat yang diperoleh dikeringkan dengan cara diuapkan di atas penangas air suhu $60^{\circ} \mathrm{C}$ hingga kering.

\section{Ekstraksi yang dihidrolisis dengan} HCL

Kecambah segar yang telah dibersihkan dikeringkan di udara terbuka dan terlindung dari sinar matahari. Setelah kering, sampel diserbukkan dengan cara diblender dan diayak dengan ayakan mesh 40. Kemudian sampel uji sebanyak $250 \mathrm{~g}$ dimasukkan ke erlemeyer, ditambahkan dengan pelarut dietil eter sebanyak $400 \mathrm{~mL}$. Dishaker selama 4 jam, disaring. Residu dishaker kembali menggunakan campuran $\mathrm{HCl} 2 \mathrm{~N}$ dan etanol $96 \%$ dengan nisbah 1:8 selama 4 jam. Campuran disaring menggunakan kertas saring Whatman nomor 41. Filtrat yang diperoleh dipanaskan pada suhu 60 ${ }^{\circ} \mathrm{C}$ di atas magnetic stirrer selama 2 jam, kemudian ekstrak dinetralkan menggunakan $\mathrm{NaHCO}_{3}$ lalu dipekatkan menggunakan rotavapor. Setelah itu, dilakukan pemisahan dengan etil asetat menggunakan corong pisah. Fraksi etil asetat yang diperoleh kemudian disaring, dan dipekatkan dengan rotavapor. Ekstrak etil asetat yang diperoleh dikeringkan dengan cara diuapkan di 
atas penangas air suhu $60{ }^{\circ} \mathrm{C}$ hingga kering.

\section{Pengujian Aktivitas Antioksidan}

Dibuat deret konsentrasi larutan kerja sampel dalam pelarut etanol, deret konsentrasi larutan kerja yang dibuat diatur sedemikian rupa sehingga nilai konsentrasi sampel yang dapat mengikat $50 \%$ radikal bebas (DPPH) berada dalam deret konsentrasi yang dibuat. Pengujian aktivitas antioksidan dilakukan dengan mengukur masing-masing $1,0 \mathrm{~mL}$ larutan kerja dimasukkan ke dalam wadah (vial) tertutup alumunium foil, kemudian ditambahkan 4,0 $\mathrm{ml}$ larutan DPPH 40 ppm. Larutan dikocok, kemudian diinkubasi selama 30 menit. Selanjutnya diukur serapannya dengan spektrofotometer UV - Vis pada panjang gelombang $517 \mathrm{~nm}$. Pengujian dilakukan dengan pengulangan (replikasi) sebanyak 3 kali. Dilakukan pula perlakuan blangko menggunakan pelarut etanol yang dicampur dengan DPPH. Kemudian dihitung \% pengikatan $(\%$ Inhibisi $)$ DPPH dan ditentukan nilai $\mathrm{IC}_{50}$ sampel

\section{HASIL DAN PEMBAHASAN}

Kedelai hitam mempunyai kandungan fenolik, tanin, antosianin dan isoflavon serta aktivitas antioksidan lebih tinggi dibanding kedelai kuning (Xu dan Chang, 2007). Menurut Xu dan Chang (2007) kedelai hitam kandungan flavonoidnya 6 kali lebih banyak dibanding kedelai kuning.

Kedelai hitam yang digunakan sebagai bahan baku dalam penelitian ini terlebih dahulu dikecambahkan. Perkecambahan dilakukan dengan tujuan untuk meningkatkan kandungan senyawa fenolik yang berfungsi sebagai zat antioksidan meningkat. Menurut Aminah dan Wikanastri (2012) nilai dan kandungan gizi kacang-kacangan menjadi lebih baik setelah melalui proses perkecambahan. Selama proses perkecambahan pada kacangkacangan sebagian sistem enzim menjadi aktif dan terjadi perubahan.

Reaksi yang terjadi selama perkecambahan meliputi hidrolisis, oksidasi, dan sintesis (Mallette et al. 1960). Reaksi hidrolisis terjadi mulai dari tahap awal perkecambahan yaitu imbibisi air. Tahap imbibisi air dapat dilakukan dengan cara perendaman dalam air atau biji diletakkan dalam lingkungan yang jenuh dengan uap air.
Pada penelitian ini, kecambah dibuat dengan cara sampel kedelai hitam berbiji kecil (varietas Malika) terlebih dahulu dicuci dengan air, kemudian direndam dalam larutan alginat $2 \% \mathrm{~b} / \mathrm{v}$. Hal ini sesuai dengan yang dikemukakan oleh Andarwulan dan Purwiyatno (2004), bahwa peningkatan komponen bioaktif selama perkecambahan pada proses perendaman dapat ditambahkan beberapa bahan-bahan sebagai larutan perendaman seperti natrium alginate $2 \%$.

Senyawa fenolik dapat diproduksi pada kacang-kacangan yang terelisitasi selama proses perkecambahan. Tumbuhan yang terinfeksi oleh mikroorganisme akan merespon dengan sistem pertahanan salah satunya dengan peningkatan produksi senyawa fenolik, sehingga dapat diperoleh kecambah kacang yang mengandung antioksidan fenol (Andarwulan dan Purwiyatno, 2001).

Kedelai hitam memiliki kadar lemak total sebesar 35,61\%, kandungan lemak yang tinggi dapat menghambat proses penarikan/ekstraksi senyawa lainnya. Oleh karena itu Proses ekstraksi dimulai dengan sampel terlebih dahulu diekstraksi pelarut dietil eter kemudian dishaker dengan kecepatan 200 rpm selama 4 jam. Pelarut dietil eter dipisahkan, dan residu dikeringkan hingga bebas dari pelarut dietil eter. Kemudian dilakukan ekstraksi dalam pelarut etanol $96 \%$ yang dicampur $\mathrm{HCl}$ dan pelarut etanol $96 \%$ tanpa $\mathrm{HCl}$, Kedua pelarut tersebut digunakan untuk menghasilkan ekstrak yang dihidrolisis dan tanpa hidrolisis. Ekstrak yang dihasilkan masing-masing difraksinasi menggunakan pelarut etl asetat untuk selanjutnya ditentukan aktivitas antioksidannya menggunakan pereaksi DPPH.

Berdasarkan Tabel 1 terlihat bahwa semakin besar konsentrasi, serapan terukur semakin kecil. Hal ini menunjukkan semakin besar konsentrasi jumlah larutan DPPH yang tereduksi semakin besar sehingga serapan terukur (sisa DPPH) semakin kecil, oleh karena itu semakin besar konsentrasi \% inhibisi (pengikatan DPPH) semakin besar pula. Adanya perbedaan konsentrasi perlakuan pada ke dua sampel ekstrak disebabkan karena pada orientasi awal penelitian ini dilakukan pencarian deret konsentrasi larutan sampel yang nilai $\mathrm{IC}_{50}$ 
berada dalam deret konsentrasi larutan sampel yang dibuat.

Hasil pengujian aktivitas antioksidan ekstrak etil asetat hasil hidrolisis dan tanpa hidrolisis, menunjukkan bahwa ada hubungan yang linear antara konsentrasi \% pengikatan radikal bebas (DPPH) seperti yang terlihat pada Gambar 1 dan 2.

Perbandingan aktivitas antioksidan ekstrak etil asetat kecambah yang telah dihidrolisis dan tanpa hidrolisis dengan $\mathrm{HCl}$ dapt dilihat pada Berdasarkan grafik hubungan konsentrasi terhadap \% inhibisi sampel, maka ditentukan nilai $\mathrm{IC}_{50}$ untuk menentukan potensi aktivitas antioksidannya. Perbandingan nilai $\mathrm{IC}_{50}$ ekstrak yang dihidrolisis dan tanpa hidrolisis dapat dilihat pada Gambar 3

Nilai $\mathrm{IC}_{50}$ ekstrak etil asetat kecambah kedelai hitam yang telah dihidrolisis terhadap pengikatan radikal bebas (DPPH) adalah sebesar 179,204 ppm. Jika dibandingkan dengan nilai IC $_{50}$ ekstrak etil asetat kecambah kedelai hitam yang tanpa hidrolisis dengan nilai $\mathrm{IC}_{50}$ sebesar 341,88 ppm. Hal ini menunjukkan bahwa ekstrak etil asetat terhidrolisis aktivitas antioksidannya lebih kuat dari ekstrak etil asetat yang tanpa hidrolisis.

Sejalan dengan penelitian Fawwaz (2014), yang menyatakan bahwa kandungan isoflavon jenis genistein pada kedelai hitam yang telah mengalami hidrolisis secara enzimatik menggunakan bakteri probiotik Lactobacillus bulgaricus adalah sebesar $4,99 \%$ (b/b), dan yang menggunakan bakteri Lactobacillus acidophilus diperoleh kadar genistein sebesar $3.46 \%$ (b/b). Penelitian David, DKK (2009) menunjukkan bahwa kandungan total isoflavon varietas kedelai yang diolah menjadi beberapa produk diantaranya kecambah kedelai memiliki kandungan total isoflavon lebih tinggi dibandingkan dengan biji kedelai. Secara alami, isoflavon pada kedelai hampir seluruhnya terdapat dalam bentuk $\beta$-glikosida (glikon). Bentuk glikosida dipertahankan oleh tanaman sebagai bentuk inaktif sehingga dibutuhkan sebagai antioksidan. Hidrolisis dengan asam atau enzim $\beta$-glukosidase dapat mengubah isoflavon glikosida menjadi isoflavon aglikon dan glukosa (Purwoko et al, 2001).

\section{KESIMPULAN}

Nilai $\mathrm{IC}_{50}$ ekstrak etil asetat kecambah kedelai hitam tanpa hidrolisis sebesar 341,88 ppm dan ekstrak terhidrolisis sebesar 179,204 ppm. Hal ini menunjukkan bahwa ekstrak terhidrolisis memiliki aktivitas antioksidan 2 kali lebih kuat dari ekstrak tanpa hidrolisis.

\section{DAFTAR PUSTAKA}

Aminah dan Wikanastri (2012) Karakteristik Kimia Tepung Kecambah Serealia Dan Kacangkacangan Dengan Variasi Blanching, Seminar Hasil-Hasil Penelitian - LPPM UNIMUS 2012

Andarwulan, N dan Purwiyatno H. Optimasi Produksi Antioksidan pada Proses Perkecambahan Biji-Bijian dan Divesifikasi Produk Pangan Fungsional. Absolut, Yogyakarta. 2001. Hal 2-3 Astuti S, Muchtadi D, Astawan M, Purwantara B, Wresdiyati T. 2009. Kualitas spermatozoa tikus yang diberi tepung kedelai kaya isoflavon, seng $(\mathrm{Zn})$ dan vitamin E. Media Peternakan 32(10): 12-21.

Devi MKA, Gondi M, Sakhtivelu G, Giridhar P, Rajasekaran T, Ravishankar GA. 2009. Functional attributes of soybean seeds and products, with reference to isoflavone content and antioxidant activity. Food Chemistry 114: 771-776.

Fawwaz, M., Akbar. N., Pratama M., Saleh, A and Baits, M. 2016. High Performance Liquid chromatographic Analysis Of Isoflavones Aglycone In Indonesian Soybean. International Journal of Pharmaceutical Sciences and Research. IJPSR ; Vol. 7(10): 42304233.

Kudou, S., Y. Fleury, D.Welti, D. Magnolato, T. Uchida, K. Kitamura and K. Okubo. 1991. Malonyl Isoflavone Glycosides in Soybean Seed (Glycine max Merrill). Agric. Biol. Chem. 55: 2227 - 2233.

Purwoko, T., Pawiroharsono, S., \& Gandjar, I. (2001). Biotransformasi isoflavon oleh Rhizopus oryzae UICC 524. BioSMART, 3(2), 7-12.

Qiushi C., 2009, Evaluate the effectiveness of the natural cosmetic product compared to chemical-based product. International Journal of Chemistry, 1, 57-59 
Wong MCY, Emery PW, Preedy VR, Wiseman H. 2008. Health benefit of isoflavones in functional foods? Proteomic and metabolomic advances. Inflammopharmacology 16(5); 235239.

Xiao CW. 2008. Health effects of soy protein and isoflavone in humans. The Journal of Nutrition 138(6): 1244-1249.

Xu B and Chang SK. 2008. Total phenolics, phenolic acids, isoflavones, and anthocyanins and antioxidant properties of yellow and black soybeans as affected by thermal processing. J. Agric. Food Chem. 56:7165-7175.

Zaheer K dan Akhtar MH. 2017. An updated review of dietary isoflavone: nutrition, processing, bioavailability and impacts on human health. Critical Review in Food Science and Nutrition 57(6):12801293.

Zhang X, Gao YT, Yang G, Li H, Cai Q, Xiang YB, Ji BT, Franke AA, Zheng W, and Shu XO. 2012.Urinary isoflavonoids and risk of coronary hearth disease. Int. J. Epidemiol. 41: 1367-1375. 


\begin{tabular}{rrrrrrr}
\hline & $\begin{array}{c}\text { Konsentrasi } \\
(\mathrm{ppm})\end{array}$ & Serapan & $\begin{array}{c}\% \\
\text { Inhibisi }\end{array}$ & $\begin{array}{c}\text { Konsentrasi } \\
(\mathrm{ppm})\end{array}$ & Serapan & $\begin{array}{c}\% \\
\text { Inhibisi }\end{array}$ \\
\hline 1 & 100 & 0,66885 & 27,96 & 100 & 0,79355 & 14,54 \\
2 & 150 & 0,54956 & 40,81 & 200 & 0,66859 & 27,99 \\
3 & 200 & 0,40916 & 55,93 & 300 & 0,51364 & 44,68 \\
4 & 250 & 0,26938 & 70,99 & 400 & 0,37868 & 59,22 \\
5 & 300 & 0,14966 & 83,88 & 500 & 0,25372 & 72,67 \\
\hline & Blanko & 0,92851 & - & Blanko & 0,92851 & - \\
\hline
\end{tabular}

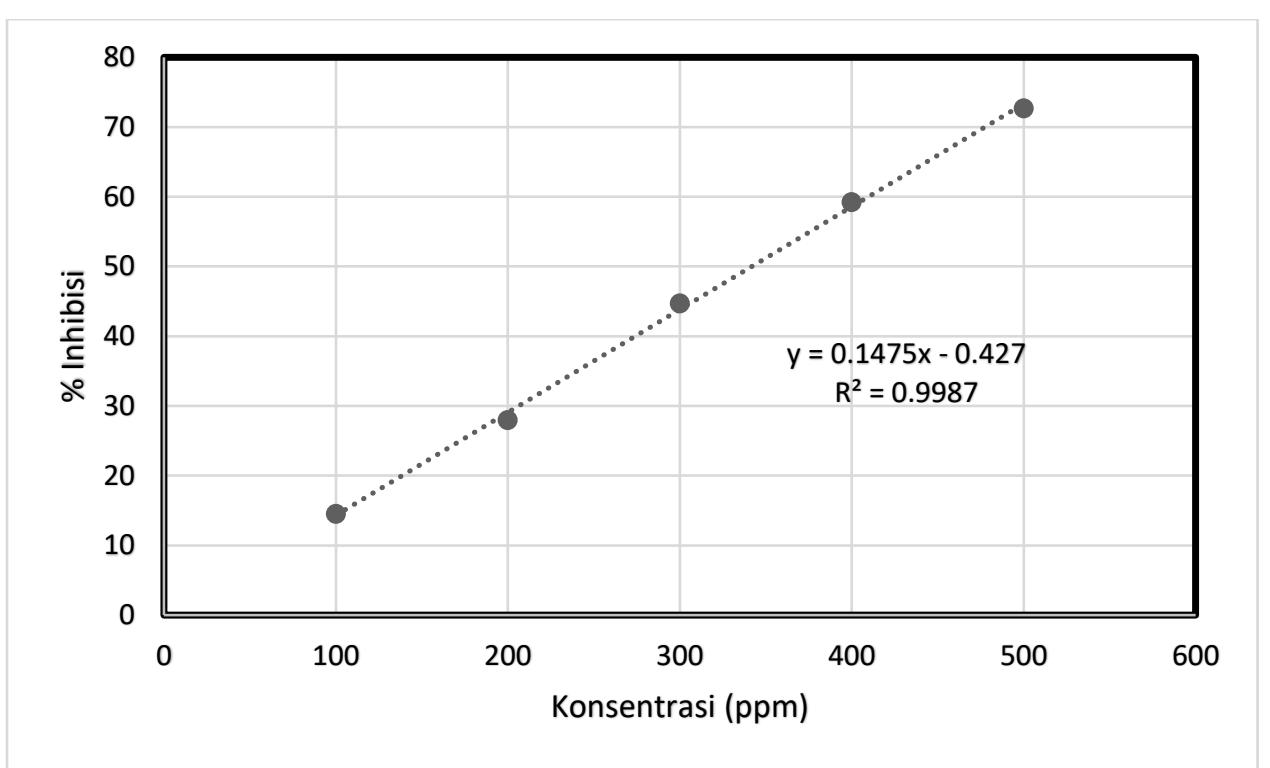

Gambar 1. Kurva hubungan konsentrasi terhadap \% inhibisi fraksi etil asetat kecambah kedelai hitam tanpa hidrolisis

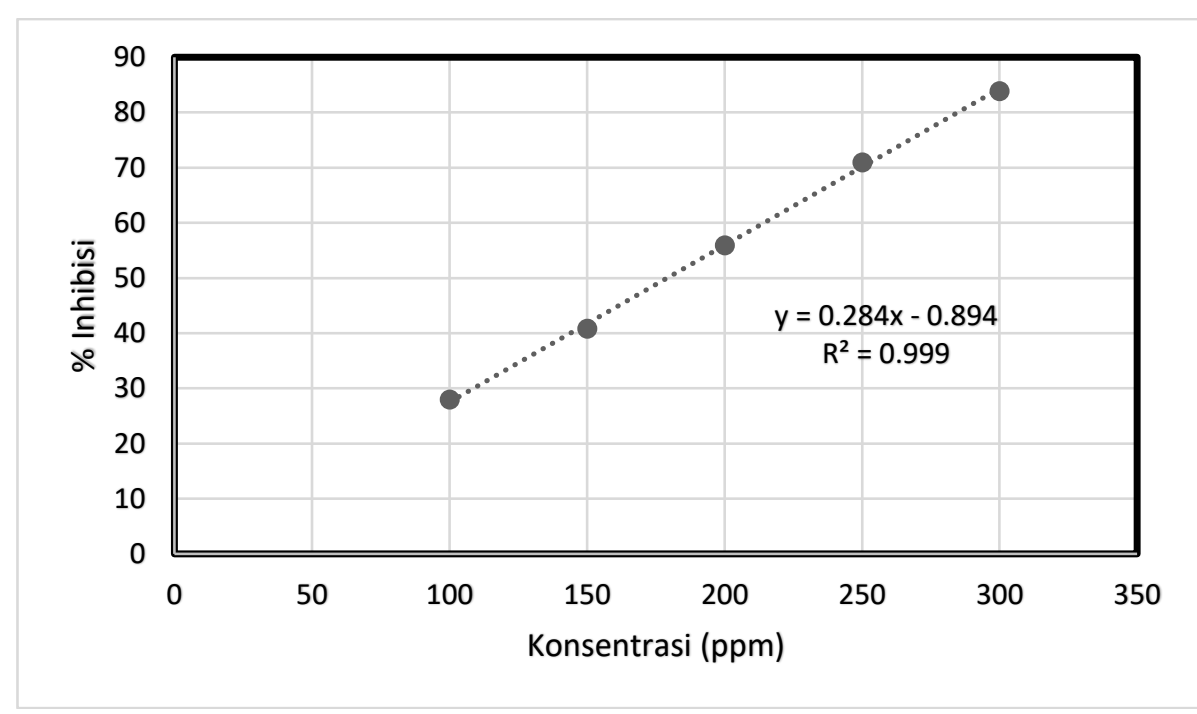

Gambar 2. Kurva hubungan konsentrasi terhadap \% inhibisi fraksi etil asetat kecambah kedelai hitam terhidrolisis 


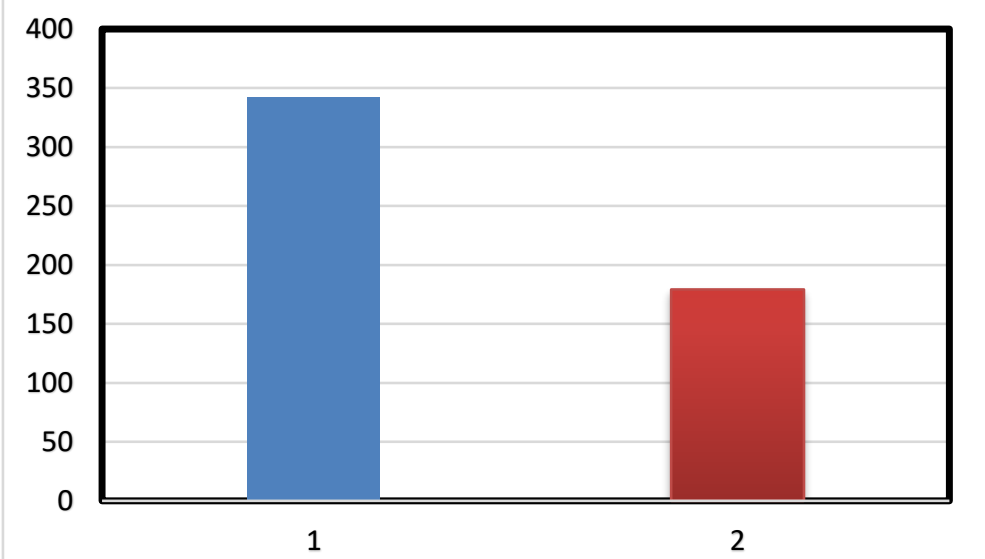

Gambar 3. Perbandingan nilai $\mathrm{IC}_{50}$ hasil pengujian aktivitas antioksidan ekstrak etil asetat kecambah kedelai hitam tanpa hidrolisis (1) dan ekstrak terhidrolisis (2) 